\title{
Changes in canola plant architecture and seed physiological quality in response to different sowing densities ${ }^{1}$
}

\author{
Elias Abrahão Jacob Junior²*, Liliane Márcia Mertz², Fernando Augusto Henning², \\ Isabel Rodríguez Quilón ${ }^{3}$, Manoel de Souza Maia ${ }^{2}$, José Maria Duran Altisent ${ }^{3}$
}

\begin{abstract}
The aim of this study was to evaluate changes in canola yield components and seed physiological quality in response to different sowing densities. The study was made in a greenhouse at the REIPESOL Company Technological Center, Madrid - Spain, with the commercial "Toccata" hybrid variety. The initial sowing density was 360,000 plants/ha and the plant population was later thinned down to include treatments of 250 and 180 thousand plants/ha. Harvested seeds were sent to the Seed Technology Center Laboratory (CATES) at the Madrid Polytechnic University (UPM) to evaluate changes in plant architecture and yield components, as well as the seed physiological quality of different plant parts. Results demonstrated that canola plants showed changes in morphology and yield components in response to different sowing densities. The population of 250,000 plants/ha showed the best seed yield demonstrating that maximum yield is directly related to a correct sowing density. The number of pods/plant was the most important component for increased seed yield/plant and seed yield/area. The spatial distribution of canola seeds in the plant and canola sowing density did not affect seed physiological quality.
\end{abstract}

Index terms: Brassica napus, yield components, seed quality.

\section{Alterações na arquitetura de plantas e na qualidade fisiológica de sementes de canola em função da densidade de semeadura}

\begin{abstract}
RESUMO - O objetivo neste estudo foi avaliar alterações nos componentes de rendimento e na qualidade fisiológica de sementes de canola, em diferentes densidades de semeadura. O experimento foi instalado em casa-de-vegetação, na Empresa REIPESOL, localizada na cidade de Madri - Espanha. Utilizou-se a variedade hibrida comercial "Toccata". Inicialmente a densidade de semeadura foi de 360 mil plantas por hectare. Posteriormente realizou-se o raleio obtendo-se as densidades de 360, 250 e 180 mil plantas por hectare. As sementes foram encaminhadas para Universidade Politécnica de Madri, onde foram avaliadas alterações na arquitetura das plantas, bem como, a qualidade fisiológica de sementes oriundas de diferentes partes da planta. As plantas de canola apresentaram alterações na morfologia e nos componentes do rendimento em resposta às variações na densidade de semeadura. A população de 250 mil plantas por hectare apresentou o melhor rendimento. O número de vagens por planta foi o componente que mais influenciou no aumento da produtividade. A distribuição espacial das sementes na planta e a densidade de semeadura não afetam a qualidade fisiológica das sementes.
\end{abstract}

Termos para indexação: Brassica napus, componentes do rendimento, qualidade de sementes.

\section{Introduction}

Canola was developed by Canadian plant breeders from rapeseed (Brassica napus L. var. oleifera), and is an attractive option for cropping systems. As a winter crop, it can be part of crop rotation systems as well as providing soil coverage.

\footnotetext{
${ }^{1}$ Submitted on 09/13/2010. Accepted for publication on 04/21/2011.

${ }^{2}$ Universidade Federal de Pelotas, Caixa Postal 354, 96010-970 - Pelotas, RS, Brasil.
}

\footnotetext{
${ }^{3}$ Departamento de Produção Vegetal, Escola Técnica Superior de Engenheiros Agrônomos, Universidade Politécnica de Madrid (UPM) - Madrid, España.

*Corresponding author <eliasajjunior@hotmail.com>
} 
Canola oil is widely used in Europe for biodiesel production, and in addition, canola meal has a high protein content and is a protein supplement in feed formulation (Franzoi et al., 2000).

However, canola use in agricultural production systems depends on knowledge of cultivation techniques, including the ideal sowing density. Many researchers have emphasized that canola sowing density is responsible for an improvement in vegetative and reproductive organs. The differential response in seed yield due to plant population variations is closely related to plant plasticity, which is the plant's capacity to change morphology and yield components in response to different sowing densities. Canola has a high plasticity and adjusts to plant population changes with the number of pods/ plant being the most important yield component in plasticity (Diepenbrock, 2000).

Many studies have been done to show that sowing density is an important factor in seed yield. Angad et al. (2003) observed that canola shows plasticity, with plant population reductions from 80 - 40 plants $/ \mathrm{m}^{2}$ not affecting seed yield, but greater reductions in plant populations did not completely compensate a lower sowing density. Sierts and Geister (1987) suggested that plant density affects the number of pods/plant, the number of seeds/plant and seed yield. Also according to Kang et al. (1988) and Oad et al. (2001), a reduction in the spacing of canola plants prolongs the growing season and delays maturation.

Changes in plant architecture and the duration of the vegetative and reproductive stages, due to variations in plant populations, can adversely affect seed physiological quality. Therefore, studies to determine the ideal sowing density are necessary to guarantee high seed yield and high physiological seed quality.

The objectives of this study were: to evaluate changes in canola plant architecture and yield components in response to different sowing densities; and to evaluate seed physiological quality from different canola plant parts in order to determine the effects of changes in plant architecture and sowing densities on seed physiological quality.

\section{Material and Methods}

\section{Plant material}

The experiment was carried out in a greenhouse belonging to the REIPESOL Company Technological Center, Madrid Spain, with the "Toccata" commercial hybrid variety. Seeds were sown in $6 \mathrm{~m} \times 1.5 \mathrm{~m} \times 1.7 \mathrm{~m}$ (length/width/depth) containers with soil fertilizers applied as needed. An initial sowing density of 360 thousand plants/ha was used and after emergence, the plants were thinned as follows: density 1 (180 thousand plants/ha); density 2 (250 thousand plants/ha) and density 3 (360 thousand plants/ha), in order evaluate variations in plant architecture and yield components. Sprinkler irrigation was daily. There were three replicates per treatment with each replicate consisting of nine plants taken at random using lottery statistics. Seeds were harvested 120 days after sowing and sent to the Center of Seed Technology Laboratory (CATES) at the Polytechnic University of Madrid (UPM) to evaluate changes in canola plant architecture and seed physiological quality.

\section{Yield components}

The number of branches, pods and seeds/plant; the number and weight of pods and seeds/branch and the seed yield/ha were measured. These evaluations were made by visual analysis (counting) and weighing with an analytical balance. To determine 1000 seed weight, eight replicates of 100 seeds were used, calculating the average weight of 100 seeds and multiplying the results by 10 . Three statistical repetitions were used.

\section{Seed quality}

The seed moisture content was: performed by the incubation method at $103^{\circ} \mathrm{C} / 17 \mathrm{~h}$, according to ISTA protocols (2009).

Germination test: with four replications on germitest paper imbibed in distilled water at a ratio of 2.5 times the paper weight. Samples were incubated in a germination chamber at $20{ }^{\circ} \mathrm{C}$. Counts were made after 4 and 8 days and normal seedling percentages calculated.

First count: carried out together with the germination test, with counts made on the fourth day and normal seedling percentages were calculated.

Cold test: with four replications on germitest paper imbibed in distilled water at a ratio of 2.5 times the paper weight. Samples were incubated at $7{ }^{\circ} \mathrm{C}$ for seven days, after which the germination test was done and normal seedling percentages calculated.

1000 seed weight

Statistical analysis: data were submitted to a variance analysis and means were compared by the Tukey test at 5\% probability, using Systat software (Wilkinson, 1990).

\section{Results and Discussion}

Plant architecture varied considerably with the sowing density (Figure 1). The numbers of branches/plant were five, four and two, plus the main inflorescence, at 
sowing densities of 180, 250 and 360 thousand plants/ha respectively. These results agree with those of Ali et al.
(1996) and Ozer (2003), who found that low sowing densities increased branch numbers on canola plants.
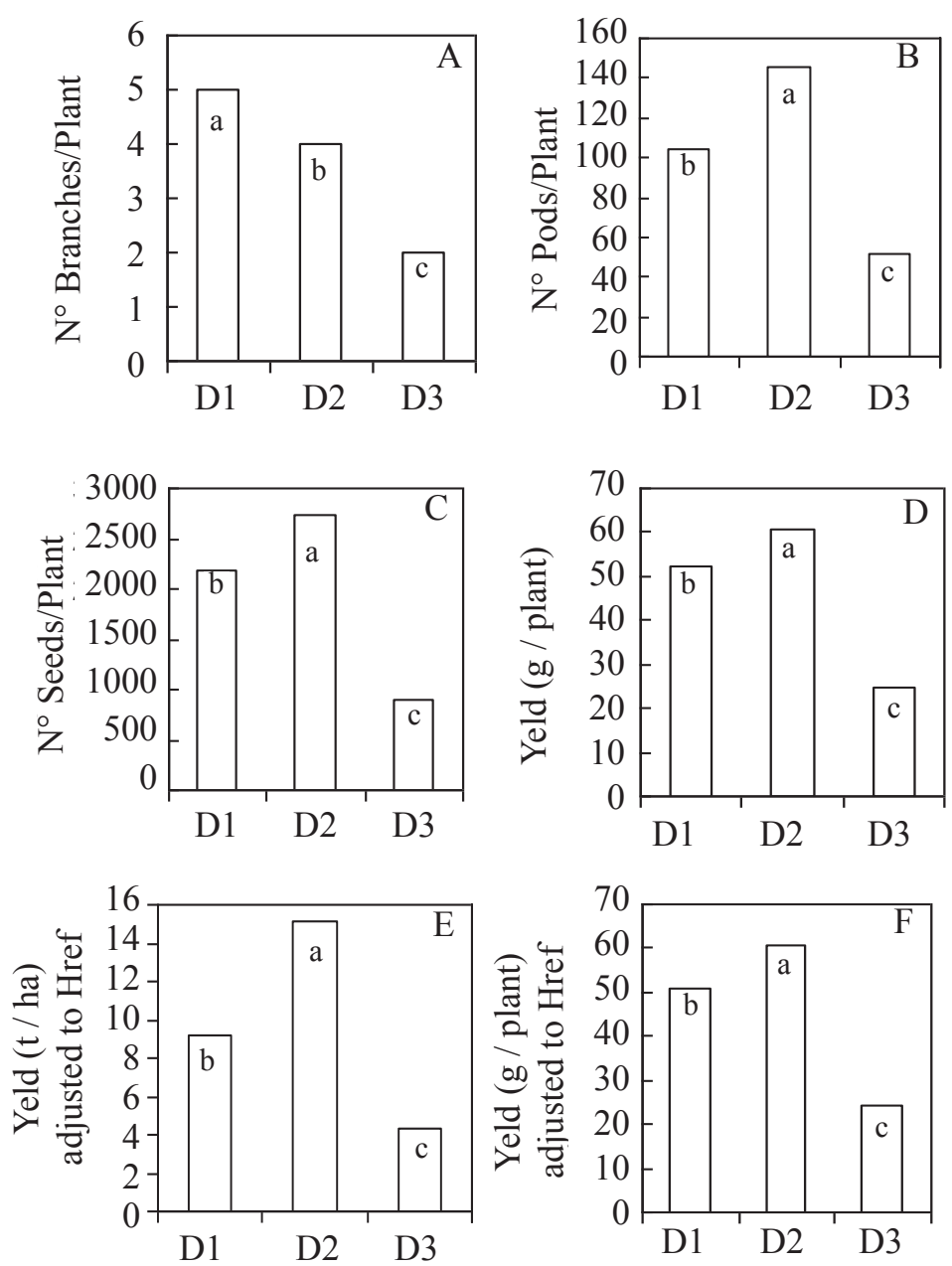

Figure 1. Canola yield components of the "Toccata" hybrid variety cultivated at three different sowing densities. D1 (180 thousand plants/ha); D2 (250 thousand plants/ha); D3 (360 thousand plants/ha). A) No of branches/plant; B) No of pods/plant; C) $\mathrm{N}^{\circ}$ of seeds/plant; D) Seed yield/plant; E) Seed yield/ha adjusted for 13\% moisture (Href), F) Seed yield/plant adjusted for $13 \%$ moisture (Href).

*Means followed by the same letter are not significantly different according to the Tukey test at $P \leq 0.05$.

The component that most contributed to differences in seed yield in response to variations in plant populations was the number of pods/plant. The numbers of pods/plant ranged from 52 to 146 with the highest value obtained at the intermediate density (250 thousand plants/ ha), followed by the density of 180 thousand plants/ha and the lowest value for 360 thousand plants/ha (Figure 1). At a density of 180 thousand plants/ha, there were more branches than at the other plant densities, but even so the number of pods/plant was highest at the intermediate density resulting in a yield increase of seeds/plant and seeds/area (Figure 1). At the higher sowing density, the number of pods/ plant was lower than for the other treatments, indicating that high sowing densities result in plants with fewer reproductive structures, resulting in lower productivity (Figure 1).

The canola plants show plasticity but the intermediate density showed the highest yield, demonstrating that the maximum yield is directly related to a correct plant density since it results in fertile pods and a seed yield increase (Figure 1). These data agree with the results obtained by Angad et al (2003), who found that reductions in sowing density from 80 to 40 plants $/ \mathrm{m}^{2}$ were mainly compensated for by an increase in pods/plant. However, in the same study, these authors found that with a greater reduction 
in plant populations to less than 40 plants $/ \mathrm{m}^{2}$, adjustment was not complete and seed yields were lower, demonstrating the need to establish the ideal sowing density.

An important aspect of this study was its execution in a greenhouse under ideal conditions and only considering intraspecific plant competition. According to Sultan (2000), plant behavior can be modified under stress conditions because the plasticity for compensating suboptimal plant populations depends on resource availability, such as water, light, nutrients and interspecific competition.
The main inflorescence was the structure that most contributed to seed yield since it produced a higher number of pods compared to the other branches (Table 1). The numbers of pods on the main inflorescence were 33, 44 and 50 for densities 3,1 and 2 respectively. For the other branches, the number of pods/branch ranged from 6 to 17 for density 1,13 to 35 for density 2 and 9 to 10 for density 3 (Table 1). For densities 1 and 2, a lower number of pods/branch was observed on branch 1 , and these structures had lower seed yields compared to other branches (Table 1).

Table 1. Canola yield components for different branches of the "Toccata" hybrid variety cultivated at three different sowing densities. D1 (180 thousand plants/ha); D2 (250 thousand plants/ha); D3 (360 thousand plants/ha).

\begin{tabular}{|c|c|c|c|c|c|}
\hline Density & Branch & $\begin{array}{c}\text { Pods/Branch } \\
\left(\mathrm{n}^{\circ}\right)\end{array}$ & $\begin{array}{l}\text { Seeds/Pod } \\
\left(\mathrm{n}^{\circ}\right)\end{array}$ & $\begin{array}{l}\text { Seeds/Branch } \\
\left(\mathrm{n}^{\circ}\right)\end{array}$ & $\begin{array}{c}\text { Seed weight/Branch } \\
(\mathrm{mg})\end{array}$ \\
\hline \multirow{7}{*}{1} & B 1 & $6 \mathrm{c}$ & $22.8 \mathrm{a}$ & $137 \mathrm{f}$ & $325.6 \mathrm{e}$ \\
\hline & B 2 & $12 \mathrm{~b}$ & $20.8 \mathrm{a}$ & $249 d$ & $565.7 \mathrm{~d}$ \\
\hline & B 3 & $11 \mathrm{~b}$ & $20.5 \mathrm{a}$ & $225 \mathrm{e}$ & $515.5 \mathrm{~d}$ \\
\hline & B 4 & $14 \mathrm{~b}$ & $21.4 \mathrm{a}$ & $299 \mathrm{c}$ & $732 \mathrm{c}$ \\
\hline & B 5 & $17 \mathrm{~b}$ & $20 \mathrm{a}$ & $340 \mathrm{~b}$ & $822.3 \mathrm{~b}$ \\
\hline & Inflorescence & $44 \mathrm{a}$ & $20.7 \mathrm{a}$ & $909 \mathrm{a}$ & $2241.2 \mathrm{a}$ \\
\hline & TOTAL & 104 & 126.2 & 2,159 & 5202.3 \\
\hline \multirow{7}{*}{2} & B 1 & $13 \mathrm{~d}$ & $17 \mathrm{a}$ & $224 \mathrm{e}$ & $490.8 \mathrm{e}$ \\
\hline & B 2 & $21 \mathrm{c}$ & $18.6 \mathrm{a}$ & $390 \mathrm{~d}$ & $860 \mathrm{~d}$ \\
\hline & B 3 & $27 \mathrm{c}$ & $19.3 \mathrm{a}$ & $520 \mathrm{c}$ & $1004.9 \mathrm{c}$ \\
\hline & B 4 & $35 \mathrm{~b}$ & $18.6 \mathrm{a}$ & $650 \mathrm{~b}$ & $1478.3 \mathrm{~b}$ \\
\hline & B 5 & $0 \mathrm{e}$ & $0 \mathrm{~b}$ & $0 \mathrm{f}$ & $0 \mathrm{f}$ \\
\hline & Inflorescence & $50 \mathrm{a}$ & $20.1 \mathrm{a}$ & $1005 \mathrm{a}$ & $2537.8 \mathrm{a}$ \\
\hline & TOTAL & 146 & 93.6 & 2,789 & 6371.8 \\
\hline \multirow{7}{*}{3} & B 1 & $9 \mathrm{~b}$ & $13.4 \mathrm{~b}$ & $121 \mathrm{c}$ & $330.2 \mathrm{c}$ \\
\hline & B 2 & $10 \mathrm{~b}$ & $18.2 \mathrm{a}$ & $182 \mathrm{~b}$ & $500.1 \mathrm{~b}$ \\
\hline & B 3 & $0 \mathrm{c}$ & $0 \mathrm{c}$ & $0 \mathrm{~d}$ & $0 \mathrm{~d}$ \\
\hline & B 4 & $0 \mathrm{c}$ & $0 \mathrm{c}$ & $0 \mathrm{~d}$ & $0 \mathrm{~d}$ \\
\hline & B 5 & $0 \mathrm{c}$ & $0 \mathrm{c}$ & $0 \mathrm{~d}$ & $0 \mathrm{~d}$ \\
\hline & Inflorescence & $33 \mathrm{a}$ & $19.7 \mathrm{a}$ & $650 \mathrm{a}$ & $1925.3 \mathrm{a}$ \\
\hline & TOTAL & 52 & 51.3 & 953 & 2755.6 \\
\hline
\end{tabular}

*Means in columns followed by the same letter are not significantly different according to the Tukey test at $\mathrm{P} \leq 0.05$.

The number of seeds/pod produced on each branch showed no significant difference between densities 1 and 2, even on the main inflorescence (Table 1). However, for density 3 , a significant difference was observed and branch 1 showed a lower number of seeds/pod compared to the other structures (Table 1).

Besides the variation in moisture content (Figure 2), differences in canola seed maturation were observed (no data presented). A large variation in values was observed even for density 2, which showed a smaller variation in seed moisture content compared to the other densities. The seed moisture content of densities 1 and 3 ranged from 6 to $40 \%$ and 6 to $30 \%$ respectively. For density 2 , more than $90 \%$ of the seeds had a moisture content ranging from 6 to $20 \%$, with a lower variation than for the other densities. 
Similar results were observed by Sims (1979) and Borba et al. (1982), who found that canola seed maturation and fruit dehiscence are irregular, resulting in losses in seed quality and quantity.
D1

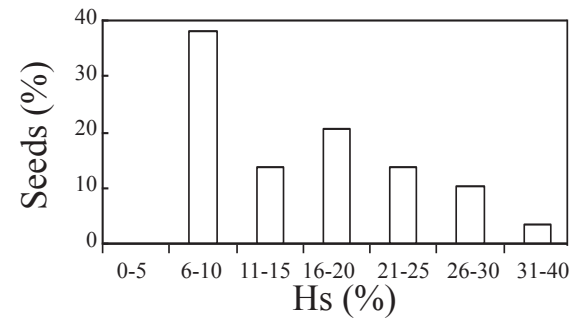

D2

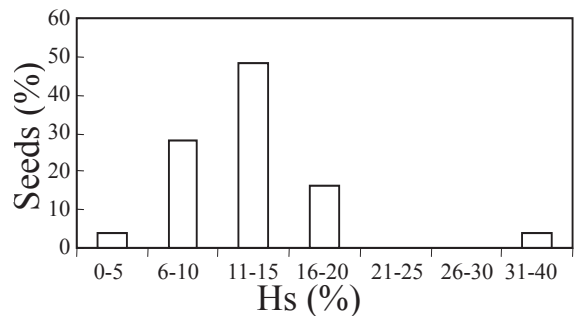

D3

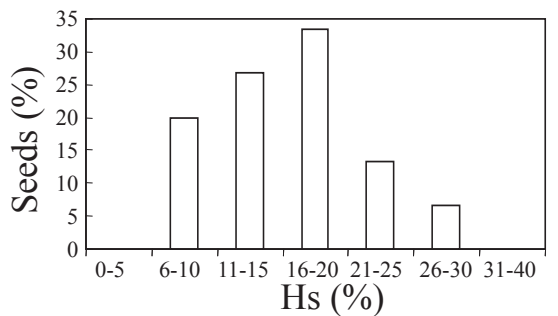

Figure 2. Canola seed moisture content of the "Toccata" hybrid variety, cultivated at three different sowing densities. D1 (180 thousand plants/ha); D2 (250 thousand plants/ha); D3 (360 thousand plants/ha).

The data from the germination, first count germination and cold tests showed no significant difference in seed physiological quality for seeds from different branches (Table 2). There was a variation between seeds from different structures, with the main inflorescence showing a higher 1000 seed weight compared to the other branches for all the densities.

Table 2. Canola physiological seed quality from different branches of the "Toccata" hybrid variety cultivated at three different sowing densities. D1 (180 thousand plants/ha); D2 (250 thousand plants/ha); D3 (360 thousand plants/ha).

\begin{tabular}{|c|c|c|c|c|c|}
\hline Density & Branch & $\begin{array}{c}\text { Germination } \\
(\%)\end{array}$ & $\begin{array}{l}\text { First Count } \\
(\%)\end{array}$ & $\begin{array}{l}\text { Cold Test } \\
(\%)\end{array}$ & $\begin{array}{l}1000 \text { seed weight } \\
\text { (mg) }\end{array}$ \\
\hline \multirow{7}{*}{1} & B1 & $100 \mathrm{a}$ & $98 \mathrm{a}$ & $97 \mathrm{a}$ & $2376.60 \mathrm{~b}$ \\
\hline & B2 & $100 \mathrm{a}$ & $99 \mathrm{a}$ & $98 \mathrm{a}$ & $2271.90 \mathrm{c}$ \\
\hline & B3 & $98 \mathrm{a}$ & $98 \mathrm{a}$ & $97 \mathrm{a}$ & $2291.10 \mathrm{c}$ \\
\hline & B4 & 99 a & $97 \mathrm{a}$ & $97 \mathrm{a}$ & $2448.20 \mathrm{a}$ \\
\hline & B5 & $100 \mathrm{a}$ & $99 \mathrm{a}$ & $99 \mathrm{a}$ & $2418.50 \mathrm{a}$ \\
\hline & Inflorescence & 99 a & $98 \mathrm{a}$ & $97 \mathrm{a}$ & $2465.60 \mathrm{a}$ \\
\hline & Average & 99 & 98 & 98 & 2378.65 \\
\hline \multirow{8}{*}{2} & B1 & $100 \mathrm{a}$ & $99 \mathrm{a}$ & $98 \mathrm{a}$ & $2191.10 \mathrm{~b}$ \\
\hline & B2 & $100 \mathrm{a}$ & $97 \mathrm{a}$ & $98 \mathrm{a}$ & $2205.10 \mathrm{~b}$ \\
\hline & B3 & $100 \mathrm{a}$ & $99 \mathrm{a}$ & 99 a & $1932.50 \mathrm{c}$ \\
\hline & B4 & $100 \mathrm{a}$ & $98 \mathrm{a}$ & $97 \mathrm{a}$ & $2274.30 \mathrm{~b}$ \\
\hline & B5 & $0 \mathrm{~b}$ & $0 \mathrm{~b}$ & $0 \mathrm{~b}$ & $0.00 \mathrm{~d}$ \\
\hline & Inflorescence & $100 \mathrm{a}$ & $99 \mathrm{a}$ & $99 \mathrm{a}$ & $2525.20 \mathrm{a}$ \\
\hline & Average & 100 & & & 2225.60 \\
\hline & B1 & $100 \mathrm{a}$ & $98 \mathrm{a}$ & $97 \mathrm{a}$ & $2731.40 \mathrm{~b}$ \\
\hline \multirow{6}{*}{3} & B2 & $100 \mathrm{a}$ & $97 \mathrm{a}$ & $96 \mathrm{a}$ & $2747.80 \mathrm{~b}$ \\
\hline & B3 & $0 \mathrm{~b}$ & $0 \mathrm{~b}$ & $0 \mathrm{~b}$ & $0.00 \mathrm{c}$ \\
\hline & B4 & $0 \mathrm{~b}$ & $0 \mathrm{~b}$ & $0 \mathrm{~b}$ & $0.00 \mathrm{c}$ \\
\hline & B5 & $0 \mathrm{~b}$ & $0 \mathrm{~b}$ & $0 \mathrm{~b}$ & $0.00 \mathrm{c}$ \\
\hline & Inflorescence & $99 \mathrm{a}$ & $97 \mathrm{a}$ & $99 \mathrm{a}$ & $2962.00 \mathrm{a}$ \\
\hline & Average & 100 & 97 & 97 & 2813.70 \\
\hline
\end{tabular}

*Means in columns followed by the same letter are not significantly different according to the Tukey test at $P \leq 0.05$. 
Changes in plant morphology resulting from different sowing densities did not affect seed physiological quality. The results from the vigor and viability tests showed that there were no significant differences in physiological quality between seeds from different plant parts or from different branches. Different plant parts showed a variation in the 1000 seed weight but this parameter did not affect seed physiological quality. The results for seed size and physiological quality were contradictory. Avila et al. (2005) observed that canola seed physiological quality was not correlated with the 1000 seed weight but McDonald Junior (1975) found that seed size influenced vigor. Studies conducted by Andrade et al. (1997) in maize showed that there were no differences in vigor between different-sized seeds. Aguiar et al. (2001) observed that there were no significant differences in physiological quality for different-sized sunflower seeds immediately after storage, although after six months small seeds showed a reduction in vigor compared to large seeds. In the present study, physiological seed quality was evaluated immediately after the harvest and, therefore, further studies are necessary to assess the correlation between these parameters during the storage period.

\section{Conclusions}

Canola plants show changes in morphology and yield components in response to different sowing densities.

Despite the high plasticity showed by the canola crop, the density of 250 thousand plants/ha gives the best yield, demonstrating that the maximum yield is directly related to the correct sowing density.

The number of pods/plant is the most important component in the increase of seed yield/plant and seed yield/area.

Spatial distribution of canola seeds in the plant and different sowing densities do not affect physiological seed quality.

\section{Acknowledgments}

The authors wish to thank CAPES and CNPq for scholarships and the Madrid Polytechnic University (UPM) for use of the facilities.

\section{References}

AGUIAR, R.H.; FANTINATTI, J.B.; GROTH, D.; USBERTI, R.; Qualidade física, fisiológica e sanitária de sementes de girassol de diferentes tamanhos. Revista Brasileira de Sementes, v.23, n.1, p.134-139, 2001. http://www.abrates.org.br/revista/artigos/2001/ v23n1/artigo 19.pdf.

ALI, M.H.; ZAMAN, S.M.H.; HOSSAIN, S.M.A. Variation in yield, oil and protein content of rapeseed (Brassica campestris) in relation to levels of nitrogen, sulphur and plant density. Indian Journal of Agronomy, v.41, p.290-295, 1996.

ANDRADE, R.V.; ANDREOLI, C.; BORBA, C.S.; AZEVEDO, J.T.; MARTINS-NETO, D.A.; OLIVEIRA, A.C. Efeito da forma e do tamanho da semente no desempenho no campo de dois genótipos de milho. Revista Brasileira de Sementes, v.19, n.1, p.62-65, 1997. http:// www.abrates.org.br/revista/artigos/1997/v19n1/artigo12.pdf.

ANGADI, S.V.; CUTFORTH, H.W.; MCCONKEY, B.G.; GAN, Y. Yield adjustment by canola grown at different plant populations under semiarid conditions. Crop Science, v.43, p.1358-1366, 2003. https://www.crops. org/publications/cs/abstracts/43/4/1358.

ÁVILA, M.R.; BRACCINI, A.L.; SCAPIM, C.A.; MARTORELLI, D.T.; ALBRECHT, L.P. Testes de laboratório em sementes de canola e a correlação com a emergência das plântulas em campo. Revista Brasileira de Sementes, v.27, n.1, p.62-70, 2005. http://www.scielo.br/pdf/rbs/ v27n1/25182.pdf.

BORBA, C.S.; BARNI, N.A.; JAMARDO, A.; GOMES, J.E.S.; GONÇALVES, J.C.; SARTORI, G. Época de colheita, rendimento de grãos e qualidade das sementes de colza (Brassica napus L. var. oleifera Metzg.). Agronomia Sulriograndense, v.18, p.39-58, 1982.

DIEPENBROCK, W. Yield analysis of winter oilseed rape (Brassica napus L.): A review. Field Crops Research, v.67, p.35-49, 2000. http:// www.sciencedirect.com/science/article/pii/S0378429000000824.

FRANZOI, E.E.; SIEWERDT, F.; RUTZ, F.; BRUM, P.A.R.; GOMES, P.C. Composição de carcaça de frangos de corte alimentados com farelo de canola. Ciência Rural, v.30, n.2, p.337-342, 2000. http://www.scielo. br/scielo.php?script=sci_arttext\&pid=S0103-84782000000200023.

ISTA. (International Seed Testing Association). International rules for seed testing. Seed Science and Technology, 24 (suppl.), 1996.

KANG, C.K.; YOO, E.Y.; LEE, P.S. The effect of nitrogen levels, potassium level and planting density on the growth and productivity of cabbage (Brassica oleracea L. var. capitata) in summer. Journal of the Korean Society for Horticultural Science, v.29, p.1-8, 1988.

McDONALD JUNIOR, M.B. A review and evaluation of seed vigor tests. Proceeding of Association of Official Seed Analysts, v.65, n.1, p.109-139, 1975.

OAD, F.C.; SOLANGI, B.K.; SAMO, M.A.; LAKHO, A.A.; HASSAN, Z.U; OAD, N.L. Growth, yield and relationship of rapeseed (Brassica napus L.) under different row spacing. International Journal of Agriculture \& Biology, v.03, p.475-476, 2001.

OZER, H. The effect of plant population densities on growth, yield and yield components of two spring rapeseed cultivars. Plant Soil Environment, v.49, p.422-426, 2003. http://www.cazv.cz/2003/PSE9_03/6-ozer.pdf. 
SIERTS, H.P.; GEISTER, G. Yield components stability in winter rape (Brassica napus L.) as a function of competition within the crop. $7^{\text {th }}$ International Rapeseed Congress, p.182, 1987.

SIMS, R.E.H. Problems of harvesting oilseed rape. Big Farm Management, v.2, p.44-57, 1979.
SULTAN, S.E. Phenotypic plasticity for plant development, function and life history. Trends Plant Science, v.5, p.537-542, 2000. http://www.cell. com/trends/plant-science/abstract/S1360-1385(00)01797-0.

WILKINSON, L. Systat: The system for statistics. Evanston, Illinois: Systat Inc, 1990. 677p. 